\title{
IMPACT OF MAHA-RERA ACT 2016 ON THE REAL ESTATE INDUSTRY
}

\author{
Swapnil Shashikant Shinde \\ Student of ME Civil (Construction management) \\ D.Y Patil Institute of Engineering and Technology, \\ Talegaon Ambi Pune Maharashtra India
}

\begin{abstract}
The enactment of Maha-RERA Act 2016 will a able to make a step forward for the sophisticated and transparency in the Real estate market for both seller and buyer. Before establishment of Maha-RERA act there was no centricity for the real and no transparency between the buyer and seller. During the enactment of the Act for the short term Real estate industry was affected by it. All the real estate projects were slow down sales marketing and also the construction work. But there are hopes that further there will be proper market establishment for the real estate industry. Adjudicating appellate tribunal department has fast track process in solving the issues in real estate project, which has given a good response to all the cases in solving the disputes related to it. Many of the terms like carpet area, promote co-promoters, sales of parking etc are point which had lots of confusion in market has been cleared in this Act..
\end{abstract}

Keywords - Watermarking, Haar Wavelet, DWT, PSNR

\section{INTRODUCTION}

For the First time a uniform legislation has been provide by the parliament of India on the subject. Before commencement of this Act, there were different regional/ state laws on the subject. In state of Maharashtra there were two important regulating construction activities popularly known as Ownership Flat scheme and Maharashtra Ownership Flats (Regulation of construction, sale, management and transfer) Act, 1963 and the rules made under, regulated the builder's promoters as to registration of the project and identities of the builder, firms and partners, as consequences thousands of illegal construction were put up by the scrupulous builder. Thousands of innocent flat purchaser have been cheated and duped by them. This necessitated uniform and effective enactment to control the situation. The RERA has necessitated uniform and effective enactment to control the situation. The RERA has provided for rigorous provision and effective machinery to protect the interest of flat purchaser and also the promoters.

\author{
Dr. Sumant Kulkarni \\ HOD of ME Civil (Construction Management) \\ D.Y Patil Institute of Engineering and Technology, \\ Talegaon Ambi Pune Maharashtra India
}

\section{LITERATURE REVIEW}

\section{A. Why RERA Matters for lenders, Srishti Ojha and Nagpur $T$ Malde lender about compliance for the real estate developers, Jan 19, 2018.}

RERA concentrate on the accountability and financial discipline be real estate developers lenders are important stake holders in the real estate sector. This article state that RERA does not creates compliance obligations for the lenders, they need to conscious of RERA related as non compliances by borrowers can create a disaster where the will create loss in the overall financing transaction. Financing documents should be strictly demanded that in case of enforcements of security relating the project, no consent/ buyers is required to notifications by Maha-RERA dated $8^{\text {th }}$ November 2017. RERA still requires consent of two third of allotees/ buyers for transfer of the rights of promoters and amalgation, demerger or merger in the protect. Under the RERA act the is no statutory right of consent actions and so it is need to specify financing documents. So this article conclude that lender should ensure solid documentation for the benefits from RERA and does not compromise their rights.

B. Immediate Impact of RERA on construction Industry, Ar Madhavi Ashok Khadar, Ar Aparna Pangati (IJER)

ISSN: 2319-6890 (onlin, 2347-5013 Vol No. 7, 11-12 Jan 2018 issue special 1 pp.: 71-74

This article states prior RERA, there was no clarity on carpet area, was sort of monopoly of builders regarding loading, rates, modes of payment. There were frauds, no clear picture of project, possessionon, sanctions. An attempt has been made to find out impact of this act on the builders and customer. The scope of study was limited to Pune area region. Concluded that Maha-RERA act 2016 is accepted by seller and buyer very easily and in future it is expected that there will be a positive impact if Act becomes more intact.

\section{Indian Real Estate: Rewind 2017, knight Frank Dated: October 30, 2018}

This article states the effects of all major effect on Real estate industry which were RERA act, Demonetization and then GST. It totally dried the Real Estate industry. Home sales went to slow down even in festive season. Season failed to bring out any change. Next 13to 18 months are likely under 
the observation period for the real estate sector is like wait and watch. Industry stake holders should spend period of reorienting business. Hopes are that India's strong economy will be still among growing economies in the world.

\section{RERA: A boon for home Buyers, vishvajeet kumar Chief Manager (Faculty) union Bank of India, Dated Nov 15, 2017.}

Explained the terms in which Home buyers will be befitted like completion of the project will on time, builders cant change for the area outside the wall as a super built-up improvement of quality as the defect liability period is for five years, transparency in deals as all the documents are displayed on RERA website and compulsion of registration before selling or advertising the project in this article it is concluded that RERA is full proof scheme to re-build trust in transparency and consumers safe guard the interest. And it will readdressed the dispute which will help to gain confidence in buyers. That's why in true sense RERA is bon for home buyers.

\section{E. Impact of Real Estate Regualtion and development Act (RERA) on India's real esate sector. Priya Chetty; (www.projectguru.in/publication) on August 14,}

Reason behind introducing the New act name RERA was real estate was facing slump since 2012 like unemployment, inventory pile up recession, low rental yield unclear and arbitration. Property prices were not stable if affected the demand and supply of the real estate sector causing the recovery of the investment for the builders. Major issue was lack of transparency. This Act addresses two major issues like delay in construction and quality of construction it is been seen 150000 complaints were registered in a single day from Noida region alone. This article states that Act aims to encourage transparency and fair practices in the sector.

\section{EXPERIMENT AND RESULT}

\section{1) Objectives}

- Impact of time and schedule on the completion of project

- Impact of finance on the real estate sector.

2) Case study 1

Below mention is the schedule of the project in the Pune Region in which it is been observed that the project is got delayed during the second slab. It was observed that the delay was occurred because the process of plinth checking. As this processes to be done by the local authority and it can be stated the duration the process and that condition the project gets delayed and for that Maha-RERA as got a solution and published a circular For this cause there is Maha-RERA as published a circular on Maharashtra Right to Public Service Act, 2015 by Government of Maharashtra Urban Development Department Mantralaya, Mumbai - 32. Government Circular no TPS - 1816/CR 452/16/UD-13 Dated: 29/11/2017 in that it is clearly mentioned the time period for the building commencement certificate, plinth checking, and occupancy certificated. Tree feeling permission as per the section 8(4) of Maharashtra (urban areas) protection and preservation of
Trees Act, 1975. Due to this it is binding on particular local authorities to complete the procedure according to the given time in the circular. Further forth slab got delayed by the 115 days during the period of the enactment of Maha-RERA act 2016. It was the condition which market was in the state of confusion so many of the builders took the stand of wait and watch. And at the end of day the project registration was carried and without registration the marketing sales was not been carried out and it affected the construction of the project as the funding the project has been stops due to which whole project was got delayed by the 5 months period and it affected the cost of the project . if the fixed expenditure is calculated the

$\begin{array}{llc}\text { Project manager salary } & = & 60,000 /- \\ \text { Site engineer Salary } & = & 35,000 /- \\ \text { Supervisor Salary } & = & 18,000 /- \\ \text { Watchman } & = & 12,000 /- \\ \text { Miscellaneous expenses } & = & 8,000 /- \\ \text { Sales \& Marketing } & = & \underline{1,00,000 /-} \\ \text { Total } & = & \underline{2,33,000 /-} \\ \text { Delay Days } & =\text { Actual Days - Estimated Days } \\ & =393-243 \\ \text { Total Months } & =149 \text { days } \\ & =150 / 30\end{array}$

Total five months expenditure $=2,33,000$ X $5=11,65,000 /$ $\%$ increase in estimated cost of the project $=(11,65,000 / 2,67,56,936) \times 100$ $=4.35 \%$ of construction cost of the project

\begin{tabular}{|c|c|c|c|}
\hline \multicolumn{5}{|c|}{ Table 1 } \\
\hline Task Name & $\begin{array}{c}\text { Baseline } \\
\text { Duration }\end{array}$ & Baseline Start & Baseline Finish \\
\hline Construction & 393 days & Thu 06-10-16 & Mon 09-04-18 \\
\hline RCC & 243 days & Thu 06-10-16 & Mon 11-09-17 \\
\hline Footing and & 40 days & Thu 06-10-16 & Wed 30-11-16 \\
\hline UGWT & & & \\
\hline Plinth & 25 days & Thu 01-12-16 & Wed 04-01-17 \\
\hline First Slab & 25 days & Tue 03-01-17 & Mon 06-02-17 \\
\hline Second Slab & $\mathbf{2 5}$ days & Tue 07-02-17 & Mon 13-03-17 \\
\hline Third Slab & 25 days & Tue 14-03-17 & Mon 17-04-17 \\
\hline Forth Slab & $\mathbf{2 5}$ days & Tue 18-04-17 & Mon 22-05-17 \\
\hline Fifth Slab & 25 days & Tue 23-05-17 & Mon 26-06-17 \\
\hline Terrace Slab & 25 days & Tue 27-06-17 & Mon 31-07-17 \\
\hline LMR and OHWT & 30 days & Tue 01-08-17 & Mon 11-09-17 \\
\hline
\end{tabular}

\begin{tabular}{|c|c|c|c|}
\hline \multicolumn{5}{|c|}{ Table } \\
\hline Task Name & $\begin{array}{c}\text { Actual } \\
\text { Duration }\end{array}$ & Actual Start & Actual Finish \\
\hline Construction & 542 days & Thu 06-10-16 & Fri 02-11-18 \\
\hline RCC & 381 days & Thu 06-10-16 & Thu 22-03-18 \\
\hline Footing and UGWT & 45 days & Thu 06-10-16 & Wed 07-12-16 \\
\hline Plinth & 19 days & Thu 08-12-16 & Tue 03-01-17 \\
\hline First Slab & 26 days & Wed 04-01-17 & Wed 08-02-17 \\
\hline Second Slab & 61 days & Wed 08-02-17 & Wed 03-05-17 \\
\hline Third Slab & 29 days & Thu 04-05-17 & Tue 13-06-17 \\
\hline Forth Slab & $\mathbf{1 1 5}$ days & Wed 14-06-17 & Tue 21-11-17 \\
\hline Fifth Slab & 35 days & Wed 22-11-17 & Tue 09-01-18 \\
\hline Terrace Slab & 32 days & Wed 10-01-18 & Thu 22-02-18 \\
\hline LMR and OHWT & 43 days & Tue 23-01-18 & Thu 22-03-18 \\
\hline
\end{tabular}




\section{International Journal of Engineering Applied Sciences and Technology, 2019 \\ Vol. 4, Issue 3, ISSN No. 2455-2143, Pages 530-532 \\ Published Online July 2019 in IJEAST (http://www.ijeast.com)}

\section{CONCLUSION}

Based on this case study it can be stated that for a short term there was impact on the real estate project of demonetization, GST and mainly Maha-RERA Act 2016. The impact was loss of financial by around 5\% and five months delay in project.

\section{REFERENCE}

[1] Ojha Srishti, Malde Nupur, "Why RERA matter for lenders";India Business Law Journal, Jan 19, 2018.

[2] Ar. Khadar Madhavi, Ar. Pangati Aparna, "Immediate Impact of RERA on Construction Industry"; International Journal of Engineering Research Vol. 7 pp 77-74. 11-12 Jan 2018.

[3] Indian Real Esate; Rewind 2017; knight Frank Dated; Octopber 30, 2018

[4] Kumar Vishwajeet Chief manager (faculty) union Bank of India, "RERA: Aboon for home buyers"; Banking Finanace News articles, dated Nov 15, 2017.

[5] Chetty Priya; "Impact of Real Estae Regualtion and Development Act ( RERA) on Idias real esate sector"; (www.projcectguru.in/publications /) on August 14, 2016.
[6] Kadam Aditya, "Detailed Study and Analysis of RERA act"; (IRJER) e-ISSN: 2395-056 Vol: 05 Issue $02 \mathrm{Apr}$ 2018

[7] Merchant Shrpad, Pednekar Rajesh, Arokar D.B, "Analysis of Dilution of the Real Estate (Regulation and Developemt) Act 2016 by State Governement"; IJCRT Vol. 6 issue April 2, 2018 issn: 2320-2882.

[8] Choudary Anita; "RERA: A Reform to Support Real Estate Sector; (Inspira JCECS) ISSN:2395-7069 Vol 04 NO. 1 Jan March 2018 pp 208-210.

[9] Kumbhar Vijay; "Beware: Registeration with RERA dosent mean the project is authentic; 28 june 2017.

[10] Patil Vasundhara; "RERA 2016 - A Game Changing step in the REAL Estate Sector"; Impact Journal, Vol.5, Issue 1 Jan 2017, 37-40

[11] Patil Somdutta, Prof Waghmare Ashish; "Influnce of RERA on Real Estate Sector"; JASRAE Vol XV, Issue No 2 April 2018

[12] Shama Ashwini Kumar; "How has the implementation of RERA imapcted real state?” Live Mint, Dec 272017 